\title{
Hyperinsulinaemic hypoglycaemia in small for dates babies
}

\author{
J E Collins, J V Leonard, D Teale, V Marks, D M Williams, C R Kennedy, M A Hall
}

\begin{abstract}
Blood glucose concentrations were measured prospectively in 27 small for dates infants in the first 48 hours after birth: 10 infants became hypoglycaemic. Of these, five had inappropriately raised plasma insulin concentrations. Plasma free fatty acids were lower and carbohydrate intake higher in these five infants, further supporting the diagnosis of hyperinsulinism. The hypoglycaemia recurred in four of the five hyperinsulinaemic infants, but in none of those who were not hyperinsulinaemic.

Hyperinsulinism is common in small for dates babies. It is important to recognise this because hypoglycaemia is likely to recur and appropriate treatment is needed to prevent long term sequelae.
\end{abstract}

Neonatal hypoglycaemia is a common problem, the causes of which are often attributed to glycogen depletion and immature gluconeogenesis. Hyperinsulinism is another cause that is well recognised in infants of diabetic mothers, and in those with the Beckwith-Wiedemann syndrome, erythroblastosis fetalis, and nesidioblastosis, but nevertheless is still widely regarded as being relatively uncommon. ${ }^{1}$ We have previously reported six infants who presented over a short period to the Hospital for Sick Children, London, however, who had unequivocal hyperinsulinism and who did not fit into any of these categories. Three of the infants were small for dates and three had been asphyxiated at birth. ${ }^{2}$ As these patients could have been highly selected we have studied prospectively small for dates infants born in one year in one unit to determine the frequency of hypoglycaemia with current management and to see if hyperinsulinism was frequent.

\section{Department of \\ Institute of Child Health, \\ 30 Guilford Street, \\ London WCIN 1EH \\ J E Collins \\ Department of \\ Clinical Biochemistry, \\ University of Surrey, \\ Guildford \\ D Teale \\ V Marks}

Paediatric Department,

Princess Anne Hospital, Southampton

D M Williams

C R Kennedy

M A Hall

Correspondence to:

Dr Leonard.

Accepted 22 May 1990

\section{Patients and methods \\ PATIENTS}

Any infant weighing less than the 10th centile for gestational age born at Princess Anne Hospital and admitted to the special baby care unit during a period of one year was eligible for study, provided full parental consent was given. Infants of mothers with carbohydrate intolerance were excluded. The total volume of blood required for the investigations was a maximum of $9 \mathrm{ml}$, and we therefore planned also to exclude infants with a birth weight of less than $1500 \mathrm{~g}$.

All the babies had blood glucose concentrations monitored by capillary puncture as part of the routine in the unit. The blood samples for this study were taken at the same time from peripheral veins.

All studies were approved by the ethical committee of Southampton and South West Hampshire Health Authority and were explained in full to the parents.

\section{METHODS}

Blood was collected in the first six hours after birth for blood glucose, free fatty acids, insulin, and $\mathrm{C}$ peptide concentrations. Further samples for the same measurements were taken as near to 12,24 , and 48 hours as possible.

Blood for measurement of glucose was collected into ice cold $0.4 \mathrm{M}$ perchloric acid in tared bottles, spun, and refrigerated within 15 minutes of collection. Separation and analysis was completed within two to three days. The sample for free fatty acids, insulin, and C peptide measurement was collected into a cold lithium heparin bottle, spun, separated, divided into two, and immediately frozen in plain tubes.

Samples for blood glucose concentration was analysed using standard enzymatic methods on an Abbott ABA 100 automatic spectrophotometer. ${ }^{34}$ Assay of insulin and $C$ peptide concentrations were by standard radioimmunoassay methods and the detection limits were $25 \mathrm{pmol} / \mathrm{l}$ for insulin and $75 \mathrm{pmol} / \mathrm{l}$ for $\mathrm{C}$ peptide. Where possible urine was collected from the infants at the same or close to the time the blood samples were taken and immediately frozen in a plain tube for $\mathrm{C}$ peptide and creatinine measurements.

Hypoglycaemia was defined as a blood glucose concentration of less than $2 \cdot 2 \mathrm{mmol} / \mathrm{l}$ and hyperinsulinism as plasma insulin concentration of more than $30 \mathrm{pmol} / \mathrm{l}(4 \mathrm{mU} / \mathrm{l})$ during hypoglycaemia.

\section{Results}

Twenty nine small for dates infants were entered into the study but two had only one blood sample collected and have been omitted. No infant was less than 32 weeks' gestation by dates, scan, or by postnatal assessment, and most were over 35 weeks (table 1). Inadvertently three patients were included who were weighed less than $1500 \mathrm{~g}(1440,1450$, and $1090 \mathrm{~g})$. The smallest baby was hypoglycaemic and all have been included in the analysis.

Seventeen of the 27 infants remained normoglycaemic throughout the study (table 1) and 10 of the 27 infants became hypoglycaemic, although none was symptomatic (table 1 ). 
Table 1 Details of babies in the study

\begin{tabular}{|c|c|c|}
\hline & $\begin{array}{l}\text { Normoglycaemic } \\
\text { group }\end{array}$ & $\begin{array}{l}\text { Hypoglycaemic } \\
\text { group }\end{array}$ \\
\hline $\begin{array}{l}\text { Blood glucose } \\
\text { concentrations }\end{array}$ & $\begin{array}{l}\text { Normoglycaemic } \\
\text { throughout (blood } \\
\text { glucose }>2 \cdot 2 \mathrm{mmol} / \mathrm{l} \text { ) }\end{array}$ & $\begin{array}{l}\text { One or more } \\
\text { blood glucose } \\
<2 \cdot 2 \mathrm{mmol} / \mathrm{l}\end{array}$ \\
\hline $\begin{array}{l}\text { No of babies } \\
\text { Delivery: }\end{array}$ & 17 & 10 \\
\hline Normal & 5 & 5 \\
\hline Forceps & 4 & 0 \\
\hline $\begin{array}{l}\text { Caesarean section } \\
\text { Gestation (weeks) }\end{array}$ & $\stackrel{8}{34-40}$ & $\stackrel{5}{32-40}$ \\
\hline $\begin{array}{l}\text { Mean (range) birth } \\
\text { weight (g) }\end{array}$ & $1960(1440-2330)$ & $1930(1090-2480$ \\
\hline $\begin{array}{l}\text { No }(\%) \text { mothers } \\
\text { having intravenous }\end{array}$ & & \\
\hline treatment ${ }^{*}$ & $12(70)$ & $7(70)$ \\
\hline $\begin{array}{l}\text { Apgar score: } \\
<5 \text { at } 1 \text { minute } \\
<5 \text { at } 5 \text { minutes }\end{array}$ & $\begin{array}{l}3 \\
0\end{array}$ & $\begin{array}{l}1 \\
0\end{array}$ \\
\hline
\end{tabular}

*4-5\% glucose.

\section{MATERNAL MEDICATION}

None of the mothers had been or was on any medication during pregnancy. Nineteen had an intravenous infusion of $4-5 \%$ glucose during labour. Seven of the 19 infants born to these mothers subsequently became hypoglycaemic (table 1).

\section{INFANT FEEDS}

As a routine all infants were given either an oral or nasogastric feed within three hours of birth. Healthy infants were given milk feeds alone, 60 $\mathrm{ml} / \mathrm{kg} /$ day on the first day and then $85 \mathrm{ml} / \mathrm{kg} /$ day on day two.

\section{INTRAVENOUS TREATMENT}

In addition to their routine feeds 12 babies were given intravenous fluids during this time. Six of them were hypoglycaemic. The other six were not hypoglycaemic but their clinical condition gave rise to other concerns. Two of the 12 infants were also given a bolus dose of glucose in addition to the infusion because of a low reading on BM-Test reagent strips (Boehringer), although only in one infant was hypoglycaemia confirmed when the blood glucose concentration was measured in the laboratory.

\section{HYPOGLYCAEMIC BABIES}

Five of the 10 hypoglycaemic babies had appropriate insulin concentrations throughout the time they were studied (table 2). The other five had one or more inappropriately raised insulin concentration during hypoglycaemia. Blood glucose concentrations were generally lower in the hyperinsulinaemic babies (figure) and all had blood glucose concentrations of less than $1.3 \mathrm{mmol} / \mathrm{l}$ within the first 12 hours after birth. In four of the five hyperinsulinaemic babies the hypoglycaemia recurred (figure) but it did not do so in any of the non-hyperinsulinaemic group. Although the data were incomplete the plasma free fatty acid concentrations at the time of hyperinsulinaemic hypoglycaemia were lower (mean $0.45 \mathrm{mmol} / \mathrm{l}, \mathrm{n}=4$ ) compared with the other infants whose insulin concentrations were appropriate for their blood glucose concentrations (mean $0.52 \mathrm{mmol} / \mathrm{l}, \mathrm{n}=3$ ). The hyperinsulinaemic infants all received milk orally and glucose intravenously. Two of these infants required glucose infusion rates of more than $10 \mathrm{mg} / \mathrm{kg} / \mathrm{min}$. Only two of the nonhyperinsulinaemic infants had intravenous treatment, both at normal glucose infusion rates $(<8$ $\mathrm{mg} / \mathrm{kg} / \mathrm{min}$ ) at times when they were not being fed.

Plasma C peptide concentrations were higher in the hyperinsulinaemic babies (mean 459 $\mathrm{pmol} / \mathrm{l}$ ) than in the other hypoglycaemic babies (mean $265 \mathrm{pmol} / \mathrm{l}$ ). The mean concentration in
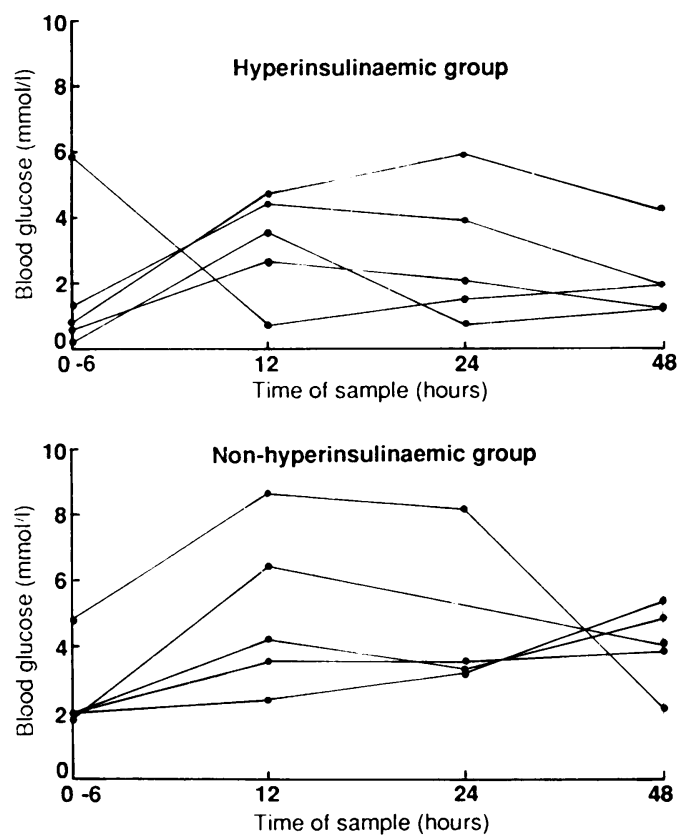

Blood glucose concentrations during the first 48 hours of life.

Table 2 Blood glucose, insulin, and $C$ peptide concentrations during hypoglycaemia

\begin{tabular}{|c|c|c|c|c|}
\hline Infant No & Age (hours) & Glucose (mmolll) & Insulin ${ }^{*}$ (pmolll) & $C$ peptide* (pmol/l) \\
\hline \multicolumn{5}{|c|}{ Non-hyperinsulinaemic group } \\
\hline $\begin{array}{l}1 \\
2 \\
3 \\
4 \\
5\end{array}$ & $\begin{array}{l}<6 \\
<6 \\
<6 \\
48 \\
<6\end{array}$ & $\begin{array}{l}2 \cdot 0 \\
2 \cdot 0 \\
2 \cdot 0 \\
2 \cdot 1 \\
1 \cdot 8\end{array}$ & $\begin{array}{l}<25 \\
<25 \\
<25 \\
<25 \\
<25\end{array}$ & $\begin{array}{l}248 \\
<75 \\
248 \\
682 \\
87\end{array}$ \\
\hline \multicolumn{5}{|c|}{ Hyperinsulinaemic group } \\
\hline $\begin{array}{r}6 \\
7 \\
7 \\
8 \\
9 \\
10\end{array}$ & $\begin{array}{l}<6 \\
<6 \\
48 \\
<6 \\
48 \\
12\end{array}$ & $\begin{array}{l}0 \cdot 6 \\
0 \cdot 2 \\
1 \cdot 2 \\
0 \cdot 7 \\
1 \cdot 9 \\
0 \cdot 7\end{array}$ & $\begin{array}{r}46 \\
179 \\
79 \\
49 \\
82 \\
66\end{array}$ & $\begin{array}{l}155 \\
310 \\
465 \\
403 \\
682 \\
744\end{array}$ \\
\hline
\end{tabular}

${ }^{*}$ Detection limit for insulin is $25 \mathrm{pmol} / \mathrm{l}$ and for $\mathrm{C}$ peptide $75 \mathrm{pmol} / \mathrm{l}$. 
the latter group was similar to the $C$ peptide concentrations in those babies who remained normoglycaemic (mean $319 \mathrm{pmol} / \mathrm{l}$ ). Overall, however, there was a poor correlation between the plasma insulin and $\mathrm{C}$ peptide concentrations (for example, babies 4 and 7, table 2).

It was not possible to collect simultaneous blood and urine samples from all the patients. Twelve samples were collected from nine infants. Urinary $C$ peptide concentrations ranged between 372 and $3100 \mathrm{pmol} / \mathrm{l}$ (242 and $1803 \mathrm{pmol} / \mathrm{mmol}$ creatinine). No correlation was found between plasma and urinary C peptide concentrations. The infant with the highest urinary $\mathrm{C}$ peptide concentration had one of the lowest plasma values.

\section{Discussion}

Many factors probably contribute to hypoglycaemia in small for dates infants. These could include lack of exogenous substrate supply, depletion of hepatic glycogen stores, defective gluconeogenesis, hyperinsulinism, and adrenocortical insufficiency. ${ }^{1}$ Some of the factors were examined by Le Dune who studied the response of small for dates babies to an intravenous glucose load or intramuscular glucagon in the first six hours of life before the first feed. ${ }^{56}$ She concluded that both hyperinsulinism and glycogen depletion contributed to the hypoglycaemia. Before the first feed insulin is still likely to be the dominant hormone, however, and giving a bolus of glucose intravenously may stimulate excess insulin release. The purpose of this study was to see if hyperinsulinism was responsible for hypoglycaemia in small for dates babies with current management. The only criteria for entry to the present study was a birth weight less than the 10th centile for gestational age, although we intended to exclude babies weighing less than $1500 \mathrm{~g}$ because of the volume of blood necessary. One very small for dates infant (1090 $\mathrm{g}$ at 32 weeks) was inadvertently included because of his hypoglycaemia and has been left in the analysis as this does not affect the conclusions. No infant was less than 32 weeks' gestation and most were near term. Although not all eligible infants were studied because of failure to obtain the blood samples, those lost were thought to be lost randomly.

Of the 27 infants studied 10 became hypoglycaemic and half of these showed evidence of hyperinsulinaemia. These babies also had higher carbohydrate requirements and slightly lower free fatty acid concentrations supporting the diagnosis of hyperinsulinism. ${ }^{1}$ The hyperinsulinaemic babies also tended to have lower blood glucose concentrations than the nonhyperinsulinaemic. The mechanism responsible for the hypoglycaemia in the other five babies is not clear. Some may have been relatively and temporarily glucagon deficient. ${ }^{7}$

We can only speculate why hyperinsulinism occurs in small for dates infants. The most likely suggestion is that it is a persistent fetal state in which islet organisation has not yet been completed and insulin is still the dominant hormone. ${ }^{18}$
Insulin and $\mathrm{C}$ peptide are produced in equimolar quantities but they are removed from the circulation at different rates. Insulin is cleared by the liver, with a half life of four to five minutes, whereas $C$ peptide is cleared by the kidney, with a half life of 11 to 30 minutes. ${ }^{9}$ It has been suggested that peripheral plasma $C$ peptide measurements might be more helpful than peripheral plasma insulin in assessing beta cell function, ${ }^{10}$ because of $\mathrm{C}$ peptide having a longer half life, the assay being relatively more sensitive, and unaffected by variations in hepatic fractional extraction in response to food. However, we found a poor association between plasma insulin and $C$ peptide concentrations in peripheral blood. We suggest that assay of $\mathrm{C}$ peptide is not a good means of assessing beta cell function in neonates, possibly because of renal immaturity and hence reduced renal clearance.

Although hyperinsulinism was clearly demonstrated in $1972,{ }^{5}$ in small for dates babies it is still not adequately recognised. This study confirms that hyperinsulinism is still frequently a cause of hypoglycaemia in small for dates infants. These infants have increased glucose requirements and go on having problems with hypoglycaemia longer than those hypoglycaemic babies who are not hyperinsulinaemic. We suggest that babies with blood glucose concentrations of less than $1.3 \mathrm{mmol} / \mathrm{l}$ are more likely to have hyperinsulinaemia. It has recently been emphasised that we are not treating neonatal hypoglycaemia aggressively enough in view of the neurodevelopmental sequelae. ${ }^{11} 12$ This is particularly important when the cause is hyperinsulinism because of the inhibition of lipolysis and hence the lack of alternative fuels for energy metabolism. Hyperinsulinaemia should be recognised in small for dates babies so that more intensive treatment can be started and continued.

1 Aynsley-Green A, Soltesz G. Hypoglycaemia in infancy and childhood. London: Churchill Livingstone, 1985.

2 Collins JE, Leonard JV. Hyperinsulinism in asphyxiated and small-for-dates infants with hypoglycaemia. Lancet 1984;ii: 311-3.

3 Barthelmai W, Czok R. Enzymatic determinations of glucose in the blood, cerebrospinal fluid and urine. Klin Wochenschr in the blood, cer

4 Noll F. L-(+)-Lactate. Determination with LDH, GPT and NAD. In: Bergmeyer HV, ed. Methods of enzymatic analysis. 2nd Ed. New York and London: Verlag Chemie Weinheim and Academic Press, 1974:1475.

5 Le Dune MA. Intravenous glucose tolerance and plasma insulin studies in small for dates infants. Arch Dis Child 1972;47:111-4

6 Le Dune MA. Response to glucagon in small for dates hypoglycaemic and non-hypoglycaemic newborn infants. Arch Dis Child 1972;47:754-9.

7 Mehta A, Wootton R, Cheng KN, Penfold P, Halliday D, Stacey TE. Effect of diazoxide or glucagon on hepatic glucose production rate during extreme neonatal hypoglycaemia. Arch Dis Child 1987;62:924-30.

8 Girard JR, Cuendet GS, Marliss EB, Keruran A, Rieutort M, Assan R. Fuels, hormones and liver metabolism at term and during the early postnatal period in the rat. $f$ Clin Invest 1973;52:3190-200.

9 Bonser AM, Garcia Webb P. C-peptide measurement and its clinical usefulness: a review. Ann Clin Biochem 1981;18: 200-6.

10 Bommen M, Stanhope R, Kurtz AM, Brook CGD. Plasma Cpeptide in hyperinsulinaemic hypoglycaemia. Arch Dis Child 1984:59:1096-8.

11 Lucas A, Morley R, Cole TJ. Adverse neurodevelopmental outcome of moderate neonatal hypoglycaemia. $\mathrm{Br}$ Med $\mathcal{F}$ 1988;297:1304-8.

12 Anonymous. Brain damage by neonatal hypoglycaemia [Editorial]. Lancet 1989;i:882-3. 